${ }^{6}$ Taylor KG, Galton DJ, Holdsworth G. Insulin-independent diabetes: a defect in the activity of lipoprotein lipase in adipose tissue. Diabetologia $1979 ; 16: 313-7$.

${ }^{7}$ Owerbach D, Bell GI, Rutter WJ, Shows TB. The insulin gene is located on chromsome 11 in humans. Nature 1980;286:82-4.

${ }^{8}$ Bell GI, Karam JH, Rutter WJ. Polymorphic DNA region adjacent to the $5^{\prime}$ end of the human insulin gene. Proc Natl Acad Sci USA 1981; 78:5758-66.

${ }^{9}$ Bell GI, Karam JH. The polymorphic locus flanking the human insulin gene: is there an association with diabetes mellitus? In: Banbury report 14: applications of recombinant DNA in human disease. Cold Spring Harbor: Cold Spring Harbor Press (in press).

10 Owerbach D, Nerup J. Restriction fragment length polymorphism of the insulin gene in diabetes mellitus. Diabetes $1982 ; 31: 275-7$.

1 Rotwein PS, Chirgwin J, Province $M$, et al. Polymorphism in the 5 '-flanking region of the human insulin gene: a genetic marker for non-insulin dependent diabetes. $N$ Engl f Med 1983;308:65-71.

12 Ullrich A, Dull TJ, Gray A, Philips JA, Peter S. Variation in the sequence and modification state of the human insulin gene flanking regions. Nucleic Acids Res 1982;10:2225-40.

${ }^{13}$ WHO Expert Committee on Diabetes Mellitus. Second report. WHO Tech Rep Ser 1980; No 646

${ }^{14}$ Kunkel LM, Smith KD, Boyer SH, et al. Analysis of human Y chromo- some specific reiterated DNA in chromosome variants. Proc Natl Acad Sci USA 1977;74:1245-9.

15 Southern EM. Detection of specific sequences among DNA fragments separated by gel electrophoresis. F Mol Biol 1975;98:503-17.

${ }^{16}$ Rigby PWJ, Dieckmann M, Rhodes C, Berg P. Labelling deoxyribonucleic acid to high specific activity in vitro by nick translation with DNA polymerase 1 . F Mol Biol 1977;113:237-51.

17 Woolf $B$. On estimating the relation between blood group and disease. Ann Hum Genet 1955;19:251-3.

${ }^{18}$ Bell GI, Selby MJ, Rutter WJ. The highly polymorphic region near the human insulin gene is composed of simple tandemly repeating sequences. Nature 1982;295:31-5.

19 Reckless JPD, Betteridge DJ, Wu P, Payne B, Galton DJ. High-density and low-density lipoproteins and prevalence of vascular disease in diabetes mellitus. $\mathrm{Br}$ Med $\mathcal{F}$ 1978; :883-6.

${ }^{20}$ Owerbach D, Billesbolle P, Schroll M, Johansen K, Poulsen S, Nerup J. Possible association between DNA sequences flanking the insulin gene and atherosclerosis. Lancet 1982;ii:1291-3.

${ }^{21}$ Bray. Obesity in perspective. NIH publication 75-708. Fogarty International Center for Advanced Study, 1973.

\title{
Pigmentation and skin reaction to sun as risk factors for cutaneous melanoma: Western Canada Melanoma Study
}

\author{
J M ELWOOD, R P GALLAGHER，G B HILL，J J SPINELLI，J C G PEARSON，W THRELFALL
}

\begin{abstract}
Between 1 April 1979 and 31 March 1981, 904 residents of the four western provinces of Canada (population 6.5 million), were diagnosed as suffering from primary cutaneous malignant melanoma. Of 801 patients aged 20-79 years, $665(83 \%)$ were interviewed along with control subjects chosen at random from the general population and matched for age, sex, and province. After exclusion of 70 subjects with lentigo maligna or acral lentiginous melanoma, comparisons of the 595 casecontrol pairs showed that light hair, skin, and eye colour, a history of heavy freckling in adolescence, and a tendency to burn readily and tan poorly in the sun were significant risk factors for melanoma. The strongest primary associations were with blond hair (relative risk $7 \cdot 1$ compared with black hair), light colour of unexposed skin (relative risk $2 \cdot 4$ ), and severe freckling (relative risk $2 \cdot 1)$. These associations were independent of ethnic origin and of recorded amount of exposure to the sun and were somewhat stronger for superficial spreading than for nodular melanoma.
\end{abstract}

This study is the largest and most detailed of an incident series of melanomas to be published to date. The results were consistent with other studies reporting associations between melanoma and poor tanning ability, a tendency to burn easily, and a history of sunburn and showed that light hair colour was the strongest risk factor for the disease.

\section{Introduction}

Malignant melanoma is of concern because of the rapid increases in incidence and mortality rates which have been seen in almost all white populations with available data, including Canada, the United States, Australia, the United Kingdom, and several other European countries. ${ }^{1-5}$ In Canada mortality rates doubled in a recent 15 year period, making melanoma one of the most rapidly increasing tumours. ${ }^{1}$ The incidence of melanoma and mortality of the disease increase with decreasing latitude in Australia, in the North American continent, and within England and Wales, although in Europe the geographical pattern is more complex because of ethnic and social factors. ${ }^{4-9}$ Patients with melanoma reportedly tend to have lighter complexion, hair, and eye colour, ${ }^{10-13}$ although the early studies that documented these features were limited in that the groups of subjects with whom patients with melanoma were compared were either undefined or included patients with other skin complaints and non-melanomatous skin cancer. While two more recent casecontrol studies showed such differences in pigmentation, ${ }^{14} 15$ two others showed no major differences. ${ }^{16} 17$

Our report is the first from the Western Canada Melanoma Study; 904 incident cases of primary cutaneous melanoma were ascertained, representing all new diagnoses for a continuous geographical area with a population of 6.5 million. Each subject interviewed was matched with a control subject chosen from the general population, and a detailed interview was carried out in the subject's home. This report is based on 595 subjects aged 20-79 years with superficial spreading or nodular melanoma and their matched controls and examines the characteristics of pigmentation and reaction of the skin to sun. 


\section{Subjects and methods}

Reports on all histologically confirmed cases of malignant melanoma newly diagnosed in Western Canada (Manitoba, Saskatchewan, Alberta, and British Columbia) during 1 April 1979 to 31 March 1981 were obtained through the treatment centres and cancer registries of each of the four provinces and patients aged 20-79 years interviewed. Each eligible patient was matched for sex and age ( \pm 2 years) and by province of residence with a control subject. Controls were selected at random from medical insurance plan lists of subscribers, which include virtually the entire adult population of each province. Patients and controls were interviewed in their homes by trained interviewers using a standardised questionnaire. Information was obtained concerning host factors, history of places of residence, occupation, recreational and vacational habits with specific reference to outdoor exposure, medical history, chronic drug use, family history, certain aspects of diet, and, for women, reproductive history and use of oral contraceptives and oestrogenic drugs.

Colour of skin and hair was determined by direct comparison with samples made up specially for the project. Skin colour was evaluated twice, on an area not exposed to the sun (upper inner arms) and an area exposed to the sun (dorsum of hands). Eye colour was recorded directly by the interviewer from observation. Sensitivity to sunburning and tanning as an adult and in childhood was recorded, as well as the amount of freckling in childhood. Patients were also asked to indicate the colour of their hair during childhood using the hair samples.

For each patient a standardised abstract of the medical record was made and pathological slides reviewed in a standardised manner by one of two pathologists (Dr A Worth, Dr W S Wood) at the Cancer Control Agency of British Columbia. Material for review could not be obtained for $121(20 \%)$ of the patients, and for these the original pathology report was used.

In the two year period 904 patients with newly diagnosed first primary cutaneous melanomas were registered, of whom 801 were aged $20-79$ years. Of these, $665(83 \%)$ were interviewed along with a matched control. Of those not interviewed, 21 had died and 40 were not located. In 21 cases the patient's physician thought that an interview would be inappropriate, and the remaining 54 subjects declined to take part. Of the 665 subjects who were interviewed, 56 had lentigo maligna melanoma and 14 acral lentiginous melanoma. Since the clinical and epidemiological features of these subtypes are apparently quite different from other melanomas, ${ }^{18} 19$ this analysis is restricted to the remaining 595 subjects; of these, 415 had superficial spreading melanoma, 128 nodular melanoma, 23 unclassified melanomas, and 29 borderline melanomas.
In Manitoba, Saskatchewan, and Alberta the study coordinators were allowed access to the provincial microfiche listing of medical plan subscribers, and subjects selected as potential controls were then telephoned to request their cooperation; $59 \%$ of those contacted agreed to participate. In British Columbia a letter requesting participation was sent out by the government Medical Services Commission and subjects had to send back a completed consent form; no telephone contact was used. This gave a response rate of $48 \%$.

The present report deals primarily with host factors. For hair colour, subjects whose hair had changed colour gave information on their hair colour in childhood, and this information was used after an adjustment based on the usual trend to dark hair colour in adult life compared with childhood seen in the data for all subjects with a natural adult hair colour. Crude associations were based on matched pair odds ratios as an estimate of relative risk. To adjust for other factors a multiple logistic model based on matched pairs was fitted using the generalised linear interactive modelling procedure. ${ }^{20} 21$ Statistically significant results were those where the two sided $p$ value was less than 0.05 , based on the change in log likelihood for the multivariate model.

Differences in risks for different subgroups were investigated by extending the model using interaction terms between risk and subgroup factors. This provided risk estimates for the subgroups, and the significance of the gain in precision of this extended model compared with the simple model with common risks for all subgroups was assessed from the change in log likelihood.

\section{Results}

Pigmentation-Significant differences were seen between cases and controls for hair colour, colour of unexposed skin on the inner aspect of the upper arm, and for eye colour, the patients with melanoma having lighter colouring. The relative risks were 9.7 for blond compared with black hair, 3.4 for light compared with dark skin, and 1.6 for blue compared with brown eyes (table I); each of these factors considered alone was statistically significant. After adjustment of each factor for the others and for other factors to be described, blond hair was associated with a relative risk of $7 \cdot 1$ compared with black hair, with a regular trend in risk over intermediate colours being seen $(p<0.001)$. Light inner arm skin colour compared with dark had a relative risk of $2 \cdot 4(p<0 \cdot 05)$. The increased risk in blue eyed compared with brown eyed subjects was small and non-significant after adjustment for hair and skin colour (relative risk 1.2).

TABLE I-Associations between pigmentation factors, sun reaction and sunburn, and ethnic origin and risk of malignant melanoma; 595 patients* with cutaneous melanoma, excluding lentigo maligna, and population based matched controls

\begin{tabular}{|c|c|c|c|c|c|}
\hline Factor & Category & Cases $(\%)$ & Controls (\%) & \multirow{8}{*}{ 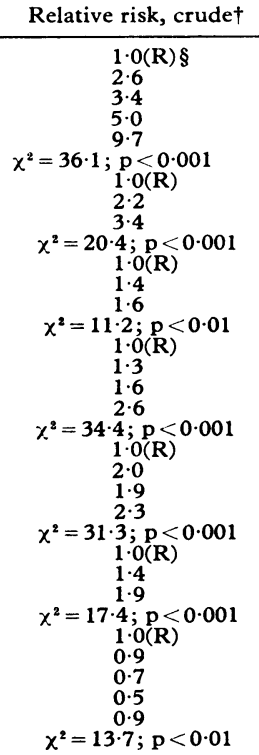 } & \multirow{8}{*}{ 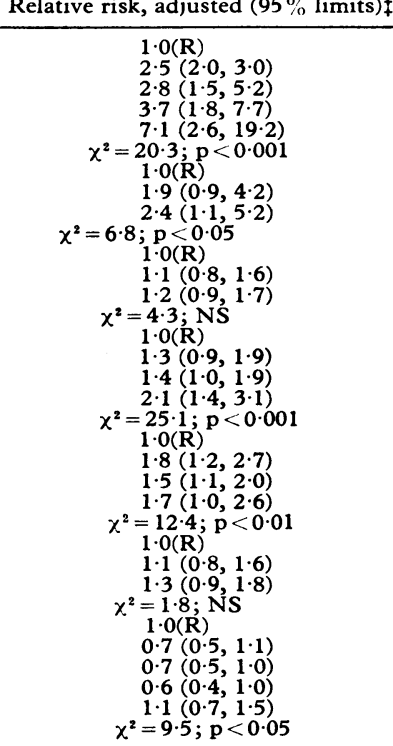 } \\
\hline Hair colour & $\left\{\begin{array}{l}\text { Black } \\
\text { Dark brown } \\
\text { Brown } \\
\text { Light brown and red } \\
\text { Blond }\end{array}\right.$ & $\begin{array}{r}3 \\
39 \\
41 \\
13 \\
5\end{array}$ & $\begin{array}{r}8 \\
44 \\
38 \\
8 \\
2\end{array}$ & & \\
\hline Skin colour & $\left\{\begin{array}{l}\text { Dark } \\
\text { Medium } \\
\text { Light }\end{array}\right.$ & $\begin{array}{r}2 \\
28 \\
70\end{array}$ & $\begin{array}{r}6 \\
35 \\
60\end{array}$ & & \\
\hline Eye colour & $\left\{\begin{array}{l}\text { Brown } \\
\text { Grey, green, hazel } \\
\text { Blue }\end{array}\right.$ & $\begin{array}{l}19 \\
27 \\
54\end{array}$ & $\begin{array}{l}27 \\
27 \\
46\end{array}$ & & \\
\hline Freckles in adolescence & $\left\{\begin{array}{l}\text { None } \\
\text { Few } \\
\text { Some } \\
\text { Many }\end{array}\right.$ & $\begin{array}{l}45 \\
13 \\
21 \\
21\end{array}$ & $\begin{array}{l}60 \\
13 \\
18 \\
10\end{array}$ & & \\
\hline Sun reaction & $\left\{\begin{array}{l}\text { Tan, no burn } \\
\text { Tan with protection } \\
\text { Burn then tan } \\
\text { Burn only }\end{array}\right.$ & $\begin{array}{l}31 \\
13 \\
42 \\
14\end{array}$ & $\begin{array}{l}47 \\
10 \\
34 \\
10\end{array}$ & & \\
\hline Childhood sunburn & $\left\{\begin{array}{l}\text { Rare or mild } \\
\text { Moderate or infrequent } \\
\text { Severe or frequent }\end{array}\right.$ & $\begin{array}{l}24 \\
27 \\
49\end{array}$ & $\begin{array}{l}15 \\
25 \\
60\end{array}$ & & \\
\hline Ethnic origin & $\left\{\begin{array}{l}\text { English } \\
\text { Celt, Scandinavian } \\
\text { West European } \\
\text { East or south European } \\
\text { Other }\end{array}\right.$ & $\begin{array}{r}40 \\
19 \\
14 \\
5 \\
21\end{array}$ & $\begin{array}{l}33 \\
19 \\
18 \\
10 \\
20\end{array}$ & & \\
\hline
\end{tabular}

* Of the 595 case-control pairs, 12 were excluded from multivariate analysis because of missing information.

$\dagger$ Unadjusted relative risk, based on matched pairs, and $p$ value.

Relative risk, adjusted for other factors shown by matched logistic analysis, and $p$ value.

$\$ \mathbf{R}=$ Reference group. 
Freckles in adolescence-Subjects who reported that in childhood and adolescence (age 5-15) they had had a "great many obvious freckles, noticed by most people" on the face showed a crude relative risk of 2.6 and a relative risk of $2.1 \quad(p<0.001)$ after adjustment for other factors, while lesser degrees of freckling were associated with lower risks.

Reaction to sun and sunburn-Subjects were asked how they tended to react to strong sunlight $(a)$ for the first time each summer and $(b)$ after a few days' exposure. The results for the two questions were similar, with those for a few days' exposure being the stronger. Compared with subjects who would "usually get a brown suntan without burning," those who would "only get sunburn and rarely get a tan" showed a crude relative risk of 2.3 ; however, after adjustment for pigmentation characteristics this fell to $1.7(p<0.01)$. A history of severe or frequent sunburns in childhood showed a crude relative risk of 1.9 , but this became smaller $(1 \cdot 3)$ and non-significant after adjustment for pigmentation factors.

Ethnic origin-Questions on ethnic origin were included, as this is related to pigmentation. The strongest association was the low risk $(0 \cdot 5)$ in subjects of east or south European origin compared with those of English origin. The associations were, however, little changed by adjustment for other factors, the differences remaining significant $(p<0 \cdot 05)$. Inclusion of ethnic origin did not substantially change the associations seen with pigmentation factors or freckling.

\section{Discussion}

These results apply to four sets of variables that are important in melanoma-pigmentation, freckles, reaction to sun, and ethnic origin.

Of the pigmentation variables, hair colour showed the strongest associations, while light colouring of usually unexposed skin had a small additional risk. These associations were somewhat stronger for patients with superficial spreading melanoma. The greater risk in fair haired and fair skinned subjects seen in this white population accorded with the large differences between white populations and black and oriental populations in risk of melanoma ${ }^{22}$; subjects with less melanocyte based pigmentation had a higher risk of melanoma. Blue eyes was a substantial risk factor considered alone, but the association was almost completely explained by colour of hair and skin. Several early studies gave results consistent with these, although those studies used undefined or unsatisfactory groups for comparison - for example, patients with other skin cancers or diseases. ${ }^{10-13}$ Two more recent studies used population based controls and gave similar results, ${ }^{14} 15$ while two other studies showed no differences in pigmentation-namely, a Norwegian study

TABLE II-Relative risks for pigmentation and sun reaction after adjustment for other factors listed for subjects with melanoma classified by subtype and primary site

\begin{tabular}{|c|c|c|c|c|c|c|c|}
\hline \multirow[b]{2}{*}{ Subgroup } & & \multicolumn{2}{|c|}{ Subtype* } & \multicolumn{4}{|c|}{ Subsite $†$} \\
\hline & & $\begin{array}{l}\text { Superficial } \\
\text { spreading } \\
\text { melanoma }\end{array}$ & $\begin{array}{l}\text { Nodular } \\
\text { melanoma }\end{array}$ & $\begin{array}{c}\text { Head and } \\
\text { neck }\end{array}$ & Trunk & Arm & Leg \\
\hline $\begin{array}{l}\text { No of cases } \\
\text { Hair colour }\end{array}$ & $\left\{\begin{array}{l}\text { Black } \\
\text { Dark brown } \\
\text { Brown } \\
\text { Light brown and red } \\
\text { Blond }\end{array}\right.$ & $\begin{array}{l}412 \\
1 \cdot 0 \\
2 \cdot 9 \\
3 \cdot 3 \\
4 \cdot 1 \\
9 \cdot 3\end{array}$ & $\begin{array}{l}127 \\
1.0 \\
1.4 \\
1.3 \\
2.6 \\
3.7\end{array}$ & $\begin{array}{l}83 \\
1 \cdot 0 \\
1 \cdot 1 \\
1 \cdot 4 \\
0 \cdot 6 \\
1 \cdot 3\end{array}$ & $\begin{array}{l}191 \\
1.0 \\
3.8 \\
3.0 \\
6.8 \\
6.9\end{array}$ & $\begin{array}{c}132 \\
1 \cdot 0 \\
2 \cdot 1 \\
2 \cdot 9 \\
3 \cdot 2 \\
\ddagger\end{array}$ & $\begin{array}{l}175 \\
1.0 \\
2.7 \\
2.7 \\
3.6 \\
8.5\end{array}$ \\
\hline Skin colour & $\left\{\begin{array}{l}\text { Dark } \\
\text { Medium } \\
\text { Light }\end{array}\right.$ & $\begin{array}{l}1 \cdot 0 \\
2 \cdot 2 \\
2 \cdot 4\end{array}$ & $\begin{array}{l}1.0 \\
1 \cdot 1 \\
1.9\end{array}$ & $\begin{array}{l}1 \cdot 0 \\
2 \cdot 2 \\
3 \cdot 0\end{array}$ & $\begin{array}{l}1 \cdot 0 \\
3 \cdot 9 \\
3 \cdot 1\end{array}$ & $\begin{array}{l}1 \cdot 0 \\
1 \cdot 1 \\
1 \cdot 2\end{array}$ & $\begin{array}{l}1 \cdot 0 \\
1.0 \\
1.9\end{array}$ \\
\hline Freckles & $\left\{\begin{array}{l}\text { None } \\
\text { Few } \\
\text { Some } \\
\text { Many }\end{array}\right.$ & $\begin{array}{l}1 \cdot 0 \\
1 \cdot 3 \\
1 \cdot 5 \\
2 \cdot 1\end{array}$ & $\begin{array}{l}1 \cdot 0 \\
0 \cdot 6 \\
1 \cdot 1 \\
1 \cdot 9\end{array}$ & $\begin{array}{l}1 \cdot 0 \\
0 \cdot 4 \\
1 \cdot 8 \\
2 \cdot 9\end{array}$ & $\begin{array}{l}1 \cdot 0 \\
1 \cdot 9 \\
1 \cdot 4 \\
2 \cdot 2\end{array}$ & $\begin{array}{l}1 \cdot 0 \\
1 \cdot 9 \\
1 \cdot 7 \\
2 \cdot 1\end{array}$ & $\begin{array}{l}1 \cdot 0 \\
1 \cdot 0 \\
1 \cdot 0 \\
1 \cdot 9\end{array}$ \\
\hline Sun reaction & $\left\{\begin{array}{l}\text { Tan, no burn } \\
\text { Tan, if protected } \\
\text { Burn then tan } \\
\text { Burn only }\end{array}\right.$ & $\begin{array}{l}1 \cdot 0 \\
1 \cdot 6 \\
1 \cdot 4 \\
1.4\end{array}$ & $\begin{array}{l}1 \cdot 0 \\
2 \cdot 0 \\
1 \cdot 5 \\
1 \cdot 3\end{array}$ & $\begin{array}{l}1 \cdot 0 \\
0 \cdot 9 \\
1 \cdot 4 \\
7 \cdot 6\end{array}$ & $\begin{array}{l}1 \cdot 0 \\
1 \cdot 6 \\
1 \cdot 1 \\
0.6\end{array}$ & $\begin{array}{l}1 \cdot 0 \\
1 \cdot 7 \\
1 \cdot 9 \\
1 \cdot 4\end{array}$ & $\begin{array}{l}1 \cdot 0 \\
2 \cdot 1 \\
1 \cdot 8 \\
2 \cdot 1\end{array}$ \\
\hline
\end{tabular}

* Excluded are four cases with missing data and 46 with unclassified or borderline melanoma. $\dagger$ Excluded are four cases with missing data, four axillary and three subungual tumours, and three with no precise site recorded.
$\ddagger$ Insufficient data.

Type of tumour, primary site, sex, age, and province-Analyses were performed separately for the 415 subjects with superficial spreading melanoma and 128 subjects with nodular melanoma (table II). While the associations with hair and skin colour appeared to be weaker for nodular than for superficial spreading melanoma, the differences between the risks for the two subtypes were not statistically significant for any variable. This analysis was repeated using only subjects on whom pathological review had been completed, with no substantial differences in the results. Analysis by primary site similarly showed no statistically significant differences between sites in their associations with any of the factors studied, although tumours of the head and neck showed a weaker relation with hair colour and a stronger one with sun reaction compared with tumours of other sites. Analyses subdivided by sex, age, and province of residence showed no significant or substantial differences.

Adjustment for recorded exposure to sun-The questionnaire included extensive questions on occupation, regular recreational activities, and vacations, with particular attention given to outdoor exposure in terms of time, place, activities, and clothing. Estimates of ultraviolet exposure over the last decade and at each decade of life were made, which will be reported in detail elsewhere. The analyses for host factors were repeated, including the ultraviolet estimates in the model, thus adjusting for differences in estimated ultraviolet exposure, and also within broad categories of extent of exposure. The factors described were not substantially changed in terms of risk or statistical significance by these adjustments. comparing 78 patients suffering from melanoma with 131 controls with cancers of sites other than skin, ${ }^{16}$ and a study in Scotland comparing 113 patients with melanoma with an undefined control group. ${ }^{17}$ These negative results may have been due to a combination of small numbers and the degree of homogeneity of the source populations.

An association with freckling would be expected, as freckles and light skin colour occur together. ${ }^{23}$ The risk associated with heavy freckling in adolescence, however, changed little when adjusted for other pigmentation factors and so was an independent risk factor. No other studies have used this question, but Beral et al found that women in Sydney, Australia, with melanoma reported more naevi currently present than did comparison subjects and reported a greater tendency to develop visible naevi after exposure to sunlight. ${ }^{16}$ In Norway, Klepp and Magnus also reported that their patients developed freckles more easily than did the controls. ${ }^{15}$ This direct relation between melanoma and freckling suggests that freckles, or naevi, have an important role in pathogenesis. The ultrastructure of nodular and superficial spreading melanoma is similar to that of naevus cells, while that of lentigo maligna melanoma more closely resembles normal melanocytes. ${ }^{24}$ Our results are consistent with the hypothesis that superficial spreading and nodular melanomas 
develop from naevi ${ }^{25}{ }^{26}$ and suggest that superficial spreading and nodular melanoma have similar relations to characteristics of pigmentation.

Our data are consistent with other studies showing associations between melanoma and poor tanning ability, a tendency to burn easily on unaccustomed exposure, and a history of sunburn. ${ }^{10161727}$ Most of the association with poor tanning ability is indirect and due to the primary associations of risk of melanoma with pigmentation and freckles, these characteristics themselves being linked to poor tolerance of the sun. In terms of sunburn history in childhood, this suggests that rather than the occurrence of sunburn itself increasing the risk of melanoma, the risk is due to the characteristics of pigmentation associated with poor sun tolerance.

The Canadian population comprised mainly European immigrants of diverse ethnic origins. The data show no evidence that subjects of Irish, Scottish, or Welsh origin had a higher risk than those of English origin, while they do show a lower risk in those of east or south European origin; the main countries represented were Czechoslovakia, Hungary, Poland, and Italy. ${ }^{5} 9$ This accords with the relatively low incidence and mortality rates reported in those countries.

In further analyses we shall explore in more detail the relations of melanoma to reported exposure to sunlight, to occupational factors, to ethnic origin and family history, and to other factors such as drugs and diet. Plainly, however, the strong relations with these host factors reported here are not substantially changed by including measures of sun exposure or ethnic origin in the analysis.

Our study is the largest and most detailed analytical study of an incident series of melanomas published to date and uses a general population comparison group of subjects. This first report shows that light pigmentation, a history of obvious freckles in adolescence, a tendency to burn easily and tan poorly, and a history of frequent sunburn in childhood are all risk factors for melanoma in white subjects and are independent of ethnic origin. Light hair pigmentation is the strongest of these factors.

This paper was prepared on behalf of the Western Canada Melanoma Study. Participants in the study include: (co-ordinators) J Birdsell, M Grace, S Kemel, M Leinweber, and D Robson; (pathologists) W S Wood and A Worth; (consultants) A J Coldman, M L Jerry, J A H Lee, D McLean, A B Miller, P Rebbeck, and H K B Silver; (analysis) J Moody and I D Turner; and (secretaries) $\mathrm{K}$ Anderson and J Gilbert.

In addition, we are grateful to the interviewers, the subjects, and their physicians and pathologists, and to the four provincial medical services for helping with the selection of controls. Generous financial support was given by the National Cancer Institute of Canada, Health and Welfare Canada (6610-1203-53), and the Alberta Heritage Trust Funds.

\section{References}

${ }^{1}$ Elwood JM, Lee JAH. Trends in mortality from primary tumours of skin in Canada. Can Med Assoc F 1974;110:913-5.

2 Lee JAH, Carter AP. Secular trends in mortality from malignant melanoma. Fournal of the National Cancer Institute 1970;45:91-7.

${ }^{3}$ Holman CDJ, James IR, Gattey PH, Armstrong BK. An analysis of trends in mortality from malignant melanoma of the skin in Australia. Int $\mathcal{F}$ Cancer 1980;26:703-9.

4 Swerdlow AJ. Incidence of malignant melanoma of the skin in England and Wales and its relationship to sunshine. $B r$ Med f 1979;ii:1324-7.

5 Jensen OM, Bolander AM. Trends in malignant melanoma of the skin. World Health Stat $Q \quad 1980 ; 33: 2-26$.

6 Lancaster HO. Some geographical aspects of the mortality from melanoma in Europeans. Med f Aust 1956;i:1082-7.

${ }^{7}$ Elwood JM, Lee JAH, Walter SD, Mo T, Green AES. Relationship of melanoma and other skin cancer mortality to latitude and ultraviolet radiation in the United States and Canada. Int $f$ Epidemiol 1974;3: 325-32.

${ }^{8}$ Fears TR, Scotto J, Schneiderman MA. Skin cancer, melanoma, and sunlight. Am $\mathcal{F}$ Public Health 1976;66:461-4.

9 Crombie IK. Variation of melanoma incidence with latitude in North America and Europe. Br F Cancer 1979;40:774-81.

10 Lancaster HO, Nelson J. Sunlight as a cause of melanoma: a clinical survey. Med $\mathcal{F}$ Aust $1957 ; \mathrm{i}: 452-6$.
11 Pack GT, Davis J, Oppenheim A. The relation of race and complexion to the incidence of moles and melanomas. Ann NY Acad Sci 1963;100: 719-42.

12 Gellin GA, Kopf AW, Garfinkel L. Malignant melanoma. A controlled study of possibly associated factors. Arch Dermatol 1969;99:43-8.

13 Beardmore GL. The epidemiology of malignant melanoma in Australia. In: McCarthy W, ed. Melanoma and skin cancer. Sydney: Government Printer, 1972:39-64.

14 Adam SA, Sheaves JK, Wright NH, Mosser G, Harris RW, Vessey MP A case-control study of the possible association between oral contraceptives and malignant melanoma. Br $\mathcal{F}$ Cancer 1981 ;44:45-50.

$15 \mathrm{Klepp} \mathrm{O}$, Magnus K. Some environmental and bodily characteristics of melanoma patients. A case-control study. Int 7 Cancer $1979 ; 23: 482-6$.

${ }^{16}$ Beral V, Evans S, Shaw H, Milton G. Cutaneous factors related to the risk of malignant melanoma. $\mathrm{Br} \mathcal{F}$ Dermatol (in press).

17 Mackie RM, Aitchison T. Severe sunburn and subsequent risk of primary cutaneous malignant melanoma in Scotland. Br 7 Cancer 1982;46:955-60.

$18 \mathrm{McGovern} \mathrm{VJ,} \mathrm{Shaw} \mathrm{HM,} \mathrm{Milton} \mathrm{GW,} \mathrm{Farago} \mathrm{GA.} \mathrm{Is} \mathrm{malignant} \mathrm{mela-}$ noma arising in a Hutchinson's melanotic freckle a separate disease entity? Histopathology 1979;4:235-42.

19 Clark WH, Mihm MC. Lentigo maligna and lentigo-maligna melanoma. Am F Pathol 1969;55:39-67.

20 Breslow NE, Day NE. Statistical methods in cancer research. IARC Scientific Publications No 32. Lyon: IARC, 1980.

21 Baker RJ, Nelder JA. The GLIM system, release 3. Oxford: Generalised Linear Interactive Modelling. Numerical Algorithms Group, 1978.

${ }^{22}$ Crombie IK. Racial differences in melanoma incidence. Br f Cancer 1979; 40:185-93.

${ }^{23}$ Nicholls EM. Genetic susceptibility and somatic mutation in the production of freckles, birthmarks and moles. Lancet 1968;i:71-3.

24 Mishima A. Melanocyte and nevocytic malignant melanomas. Cellular and subcellular differentiation. Cancer 1967;20:632-49.

25 McGovern VJ, Caldwell RA, Duncan CA, et al. Moles and malignant melanoma: terminology and classification. Med f Aust 1967;i:123-4.

${ }^{26}$ Mackie RM. The biology of malignant melanoma, the pathology of cutaneous malignant melanoma. In: Jarrett $\mathrm{A}$, ed. The physiology and pathophysiology of the skin. London: Academic Press Inc, 1982:2180-203.

27 Beitner H, Ringborg U, Wennersten G, Lagerlof B. Further evidence for increased light sensitivity in patients with malignant melanoma. $\mathrm{Br} \mathfrak{F}$ Dermatol $1981 ; 104: 289-94$.

(Accepted 1 November 1983)

ONE HUNDRED YEARS AGO The following authenticated particulars of the case of the man named Pugh, who, whilst out with a hunting-party, encamped near Alexandretta, Syria, was bitten by a panther, and died a few weeks after his return to England, has been forwarded to us by Dr. Druce J. Slater. It appears that on January 17th, whilst the party was out after small game, one of the spaniels was heard to cry, as though held by a thorn. Pugh, who was in charge of the dogs, advanced towards the dog, when a panther, which had probably fascinated the little animal, sprang from some long grass upon Pugh, bit him severely in the left arm, near the elbow, inflicting four ugly lacerated wounds and a fracture of the radius, and throwing him to the ground. One of the beaters attacked the brute with his stick, and the spaniel, having overcome his fear also sprang at him, whereupon the panther made off, receiving in his retreat a charge of No. 7 shot in his shoulder, which, unfortunately, was not enough to stop him. Dr. Slater, as the doctor of the party, conveyed Pugh back to camp, and dressed his wounds with carbolic lotion. Inflammation set in, but was subdued by linseed-poultices. Some days later he had to enlarge one of the wounds, which was in the bend of the elbow, to allow the sloughs to escape. The patient went on well, and by March 18th, when he arrived in England, the wounds had healed, the bone united, and passive motion had improved the mobility of the joint. As there was still considerable stiffness, Mr. Willett saw the patient, and offered to take him into St. Bartholomew's, and break down the adhesions by manipulation. Pugh went to his home near Canterbury, and a day or two afterwards took cold. In the following week, Dr. Slater found him suffering from acute pneumonia. He was being attended by $\mathbf{M r}$. Hamilton of Chilham, but, in spite of that gentleman's care, he died on April 8th. The pneumonia was accompanied by delirium, and both Dr. Slater and Mr. Hamilton concur that the cause of death was not hydrophobia, as has been stated. But, interesting pathologically as such a case of hydrophobic poisoning would have been, the facts of the case do not, Dr. Slater says, warrant any association of the bite with the death. (British Medical fournal $1884 ; \mathrm{i}: 917$. 